\title{
Pola Komunikasi Kelompok Virtual dalam Game PUBG Mobile (Studi Kasus Tim Redlineze E-Sport)
}

\author{
Frinico Alfian ${ }^{1}$, Wulan Purnama Sari ${ }^{2 *}$ \\ ${ }^{1}$ Fakultas Ilmu Komunikasi, Universitas Tarumanagara \\ Email:frinico7@gmail.com \\ ${ }^{2}$ Fakultas Ilmu Komunikasi, Universitas Tarumanagara* \\ Email: wulanp@fikom.untar.ac.id
}

Masuk tanggal : 15-12-2021, revisi tanggal :06-01-2022, diterima untuk diterbitkan tanggal : 16-01-2022

\begin{abstract}
Player Unknown's Battlegrounds Mobile online game is one of online games that provide communication feature for the players which enable them to communicate each other. The communication that occurs among the players is virtual communication in which they are able to coordinate one another in order to win the game. As the aim of the team is to achieve the victory, therefore the members of the team need to have the same vision and mission. This study aims to explore the pattern of communication that occurs in a game team when the players are planning the strategy to win the game and explain how each member of the team communicate with the other members. This research is a qualitative research with case study research strategy. The researcher conducts extended interviews and observation in order to collect the data. The result of this research shows that the pattern of communication of the face to face group communication occurs as impact of the communication activity performed by each member of the team. This interaction also raises the effectivity of the communication occurs on the team.
\end{abstract}

Keywords: group communication, online game, pattern of communication

\begin{abstract}
Abstrak
Game online Player Unknown's Battlegrounds Mobile merupakan game online yang menyediakan fitur komunikasi didalamnya, sehingga antar pemain game PUBG Mobile dapat berkomunikasi untuk mengatur strategi permainan. Komunikasi yang terjadi didalamnya dapat diartikan sebagai komunikasi virtual, dimana para pemain dapat dengan mudah berkomunikasi dan menjalankan strategi kerjasama yang baik, guna mencapai tujuan bersama. Tujuan dari terbentuknya suatu kelompok atau tim ialah mendapatkan sesuatu atau mendapatkan kemenangan. Oleh karena itu, suatu tim atau kelompok harus mempuyai visi misi yang sama. Penelitian ini bertujuan untuk mengetahui bagaimana pola komunikasi kelompok yang terjadi dalam tim dalam menyusun strategi dan bagaimana cara para anggota tim membentuk komunikasi yang dapat dipahami anggota satu dengan anggota yang lainnya. Penelitian ini menggunakan metode kualitatif dengan strategi studi kasus. Peneliti menggunakan metode pengumpulan data dengan cara wawancara mendalam dan observasi. Hasil penelitian yang didapat menunjukan adanya pola komunikasi kelompok bertatap muka secara langsung yang dibentuk oleh aktivitas komunikasi dari setiap anggota dalam tim membawa pengaruh besar terhadap tim. Bentuk proses interaksi juga turut berpengaruh dalam efektivitas komunikasi dalam tim tersebut.
\end{abstract}

Kata Kunci: komunikasi kelompok, permainan daring, pola komunikasi 


\section{Pendahuluan}

Komunikasi memiliki bentuk cara baru pada saat hadirnya media siber. Selama ini pola komunikasi terdiri dari one-to-many atau dari satu sumber ke banyak audiences (seperti buku, radio, atau TV) dan pola dari sumber ke satu audience atau one-to-one (seperti telepon, surat). Adanya koneksi yang terjalin antar perangkat komputer dengan perangkat komputer lainnya, tentunya komunikasi terjadi juga pada saat tersebut. Dari penjelasan inilah kata "internet" itu muncul, yaitu menghubungkan (interconnected) komputer secara global (Nasrullah, 2014). Manusia menjadikan internet salah satu teknologi yang paling banyak digunakan pada saat ini. Karena dengan internet manusia bisa melakukan apa saja, termasuk bermain game dengan siapapun.

Melalui internet, game online dapat dimainkan, bahkan dengan multi pemain dan juga melalui perangkat komputer (Kustiawan dan Utomo, 2019). Pada tahun 2000 hingga sekarang game tumbuh subur di berbagai penjuru dunia bahkan kompetisi-kompetisi berkelas internasional mulai bermunculan dan menjadikan perkembangan e-sports tumbuh subur. Kementerian Pemuda dan Olahraga Republik Indonesia atau Kemenpora sudah mempunyai IeSPA atau Indonesia E-Sports Association. Dalam dunia game yang sangat kompetitif dan bahkan sudah bisa menjadikan game sebagai pekerjaan yang bisa disebut sebagai profesional gamers, tentunya banyak kategori yang profesional gamers tekuni seperti Dota 2, CS:GO, Valorant, PUBG Mobile.

Player Unknown's Battleground Mobile (PUBG Mobile) saat ini menjadi salah satu game online yang paling digemari. PUBG merupakan suatu game multiplayer bergenre MMOFPS (Massive Multiplayer Online First Person Shooter) yang dapat dimainkan di smartphone (mobile) atau komputer $(P C)$. Dalam setiap permainan game apapun itu, pasti mempunyai tujuan untuk mendapatkan sesuatu atau untuk mendapatkan kemenangan. Demi mencapai tujuannya pasti setiap pemain mempunyai strategi masing-masing yang dijalankan. Terlebih bermain dalam bentuk tim/kelompok lebih banyak tantangan dalam menyatukan visi misi pada setiap pemainnya.

Pada permainan PUBG Mobile juga perlu kerja sama yang baik tentunya dalam berkomunikasi antar anggota tim. Komunikasi yang terjadi di dalam PUBG Mobile dapat disebut komunikasi virtual. Menurut Dede (2018) komunikasi virtual adalah suatu perkumpulan sosial yang berkumpul dan membentuk kegiatan komunikasi melalui internet dan saling berdiskusi secara virtual dengan melibatkan pikiran dan perasaan para penggunanya. PUBG Mobile juga mempunyai karakteristik dalam permainnya, yaitu berkomunikasi dalam permainan. Karena game ini adalah game bertahan hidup sampai menjadi yang terkahir tersisa. Antar anggotanya juga akan aktif berkomunikasi dalam bermain. Dengan adanya penelitian ini, peneliti akan mencari tahu bagaimana pola komunikasi kelompok virtual antar pemain dalam bermain game.

Penelitian ini juga dilengkapi dengan adanya penelitian terdahulu, untuk mengetahui persamaan dan perbedaan dengan penelitian ini. Penelitian terdahulu yang pertama yaitu suatu karya ilmiah dari Eko Harry Susanto dengan judul "Komunikasi Sepadan Dalam Pembangunan Daerah (Studi tentang Pola Komunikasi Untuk Mewujudkan Visi Riau 2020". Penelitian Susanto tersebut berfokus kepada bagaimana pola komunikasi yang terjadi untuk mewujudkan visi Riau 2020. Sementara penelitian ini fokus pada komunikasi antar anggota tim dalam game 
online. Penelitian ini mencari peran masing-masing anggota yang terdapat dalam suatu perkumpulan / organisasi.

\section{Metode Penelitian}

Peneliti menggunakan metode penelitian kualitatif. Penelitian kualitatif adalah fakta yang didapat dari subjek penelitian yang melibatkan sikap, cara berpikir, motivasi, tindakan dan juga dapat diartikan oleh perkataan pada suatu konteks dengan menggunakan metode alamiah. Penelitian kualitatif adalah penelitian yang menggunakan penafsiran makna dari hasil penelitian yang telah didapat (Moleong, 2010). Penelitian kualitatif juga menggunakan pendekatan deskriptif - kualitatif dalam penelitian ini untuk dapat membuat penelitian secara mendalam dan menjelaskan secara gamblang tentang pola komunikasi kelompok virtual dalam game PUBG Mobile.

Studi kasus merupakan penelitian mengenai individu, kelompok atau organisasi, peristiwa secara mendalam. Tujuan penelitian ini adalah untuk mendapatkan suatu pandangan yang lebih mendetail tentang suatu kasus yang sedang diteliti. Studi kasus adalah salah satu metode dalam penelitian ilmu - ilmu sosial. Pengumpulan data yang diperoleh dapat didasarkan atas enam sumber yaitu melalui dokumentasi, rekaman arsip, wawancara, pengamatan langsung, obersvasi partisipan dan perangkat - perangkat fisik (Yin, 2014). Sebagai upaya penelitian studi kasus dapat memberi nilai tambahan pada pengetahuan kita tentang fenomena individual, organisasi, sosial dan politik. Secara singkat penelitian studi kasus membantu peneliti untuk mempertahankan karakteristik holistik dan mempunyai makna dari kejadian-kejadian nyata seperti misalnya kehidupan seseorang, proses organisasial dan manajerial, perubahan lingkungan sosial, hubungan-hubungan internasional, dan kematangan industri (Yin, 2014).

Subjek penelitian dalam penelitian ini bisa disebut sebagai informan, yang artinya orang pada latar penelitian yang dimanfaatkan untuk memberikan informasi tentang situasi dan kondisi latar penelitian. Subjek penelitian tersebut juga bisa disebut sebagai individu/komunitas/organisasi untuk mendapatkan objek yang dibutuhkan dalam penelitian ini. Peneliti juga ingin mendapatkan informasi yang jelas dari narasumber agar penelitian ini berjalan dengan mudah dan lancar.

Dalam penelitian ini menggunakan metode pengumpulan data wawancara dan observasi mendalam, dokumentasi, dan rekaman arsip. Penelitian yang dilakukan juga sudah dapat diuji data pada saat memperoleh data tersebut, dan dapat dipertanggungjawabkan. Narasumber memberikan informasi dan peneliti mendapatkan datanya. Kemudian data tersebut peneliti terjemahkan, dan hasil terjemahan tersebut akan menjadi data yang akan ditafsirkan peneliti sesuai dengan jawaban dan pengalaman para narasumber.

\section{Hasil Temuan dan Diskusi}

Redlineze E-Sports adalah sebuah tim yang menekuni bidang e-sports dari Indonesia. Tim ini muncul pada tahun 2020. Salah satu $e$-sports yang ditekuni oleh tim ini adalah Player Unkown Battlegrounds Mobile (PUBGM). Permainan ini merupakan termasuk jenis Massive Multiplayer Online First Person Shooter (MMOFPS). Permainan ini dapat dimainkan baik di komputer maupun di ponsel. 


\section{Pola Komunikasi}

Dalam membangun pola komunikasi yang baik dalam tim, setiap para anggotanya harus aktif dalam berkomunikasi, tidak hanya opinion leader saja. Komunikasi juga sebagai sarana para pemain membuat pemikiran imajiner dalam bermain. Berdasarkan data yang diperoleh peneliti, konsep pola komunikasi yang terdapat dalam tim Redlineze E-sport ini sangat efektif karena para anggota aktif berkomunikasi.

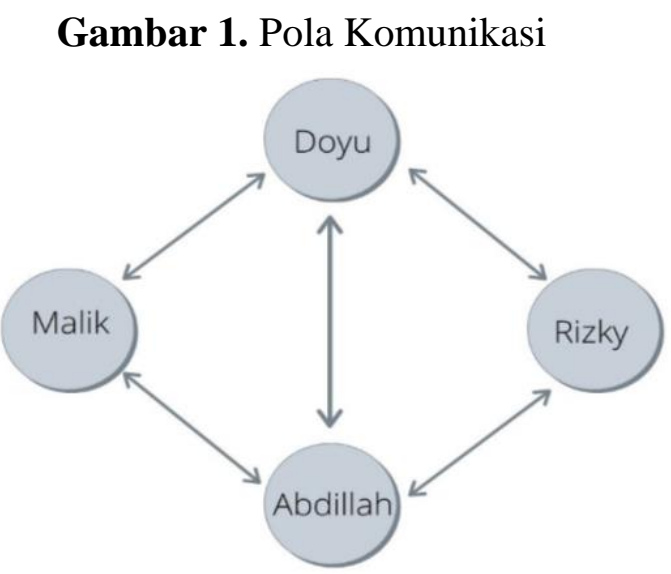

Sumber: Dokumentasi Pribadi

Melalui komunikasi, kegiatan pertukaran makna dapat terjadi dalam kehidupan sehari-hari. Miller (n.d) menyampaikan bahwa komunikasi merupakan situasi yang memungkingkan suatu sumber untuk mentransmisikan isi pesan kepada penerima pesan yang dilakukan untuk mempengaruhi perilaku seseorang secara sadar. Menurut Verderber (n.d) yaitu komunikasi sebagai fungsi sosial untuk tujuan kesenangan, membangun dan memelihara hubungan dengan orang lain untuk menunjukkan kedekatan dan sebagai fungsi pengambilan keputusan.

Berdasarkan Kamus Besar Bahasa Indonesia (KBBI) komunikasi memiliki makna pengiriman dan penerimaan pesan atau berita antara dua orang atau lebih sehingga pesan yang dimaksud dapat dipahami dan dimengerti. Dalam salah satu kasus penelitian ini, tim menggunakan komunikasi dengan fungsi pengambilan keputusan.

Menurut penjelasan dari narasumber, bahwa pada saat memilih pemimpin tim juga tetap harus dimusyawarahkan. Apalagi strategi yang tidak hanya bisa dengan mempunyai satu strategi saja, karena dalam tim masing-masing harus memberikan strateginya, dan peran pemimpin tim yang akan mengambil keputusan strategi mana yang akan dipakai. Keputusan apapun yang diambil oleh pemimpin tim, itu adalah tanggung jawab pemimpin, tapi tetap akan ada evaluasi ketika strategi tersebut berhasil atau tidaknya nanti.

Dalam komunikasi kelompok setiap individu dapat membuat pola komunikasi dalam tim, agar proses komunikasi berjalan dengan baik tidak meminimalisir kesalahpahaman yang terjadi dalam tim.

\section{Bentuk-bentuk Komunikasi}

Komunikasi dapat dibagi dalam dua bentuk. Pertama, adalah komunikasi kelompok, yaitu interaksi tatap muka antara tiga orang atau lebih dengan tujuan yang telah diketahui, seperti berbagi informasi, pemecahan masalah yang mana anggota- 
anggotanya dapat mengingat karakteristik pribadi anggota yang lain secara tepat. Kedua, adalah komunikasi organisasi, yaitu komunikasi antar manusia yang terjadi dalam konteks organisasi.

Berdasarkan wawancara dengan tim, penulis beranggapan bahwa bentuk komunikasi yang diambil oleh tim adalah komunikasi organisasi. Karena komunikasi yang mereka lakukan tidak secara tatap muka dan juga dilakukan secara non-formal. Ini dapat dilihat dari bahasa yang digunakan oleh tim. Dalam hal ini pemimpin menggunakan bahasa tak formal, serta komunikasi yang dilaksanakan juga dua arah, di mana keputusan dari pemimpin bisa diubah.

Melihat dari jenis permainan, maka komunikasi yang dijalankan juga tidak secara tatap muka. Pemain cenderung berfokus pada layar mereka, sehingga komunikasi cenderung lebih banyak dilakukan melalui voice chat. Ini menyebabkan tidak memungkinkan untuk membentuk suatu komunikasi formal.

\section{Tujuan Komunikasi}

Widjaja (2010) menjelaskan pada umumnya komunikasi juga memiliki beberapa tujuan, yaitu (1) menggerakkan orang lain untuk melakukan sesuatu, (2) memahami orang lain, (3) supaya yang kita sampaikan itu mudah dipahami, (4) supaya gagasan kita dapat diterima oleh orang lain.

Menurut wawancara narasumber, pemimpin dari tim tersebut memiliki tujuan untuk menggerakan timnya untuk melakukan sesuatu. Tentunya dalam sebuah pertandingan tujuan utamanya ialah kemenangan, itulah yang coba digerakan oleh pemimpin tim terhadap para anggota tim lainnya. Tim ini juga memiliki tujuan komunikasi untuk memahami orang lain. Menurut wawancara yang dilakukan terhadap narasumber, tujuan komunikasi yang ini sangat penting. Karena dalam tim, yang terdiri dari empat orang masing-masing harus bisa memahami satu sama lain. Demi menjaga visi dan misi yang sudah dibangun diawal pada saat membuat tim tersebut. Biasanya yang dilakukan untuk memahami orang lain ialah, saling memberikan motivasi.

Sebagai pemimpin tim, tentunya yang paling bertanggungjawab dalam tim, entah itu strategi atau perasaan pemain. Tujuan komunikasi selanjutnya ialah agar apa yang disampaikan mudah dipahami. Menurut hasil wawancara, kenapa harus ada seorang pemimpin dalam tim, ialah untuk memberikan arahan atau informasi dengan benar. Tentunya dalam pemilihan pemimpin tim juga tidak sembarangan, dipilih yang benar-benar bisa melakukan komunikasi dengan baik terhadap orang lain terkhusus untuk timnya. Karena cara penyampaian kita pada saat berkomunikasi, harus mudah dipahami oleh orang lain.

Tim ini cenderung terbuka dalam membuat keputusan. Masing-masing anggota bisa mengajukan gagasan agar diterima seluruh tim. Dalam hal ini, maka tujuan komunikasi sebagai pengajuan gagasan juga tampak pada tim, Dalam hal ini, tujuan komunikasi tim dapat tercapai dengan baik. Seluruh tim mengerti bagaimana pemimpin mereka berkomunikasi dan menghargai keputusan pemimpin tim.

\section{Komunikasi Virtual}

Menurut Shields (dalam Astuti dan Leonard, 2015), komunikasi virtual merupakan komunikasi yang terjadi di dalam ruang maya/dunia virtual yang bersifat interaktif. Virtual di sini terkait pada hubungan ruang dalam tempat, relasi, dan nilai shields (dalam Astuti dan Leonard, 2015). Ruang virtual merupakan produk dari berubahnya komunikasi sebagai lingkungan manusia. 
Seperti pemain game pada umumnya, komunikasi yang dilakukan selama pemainan PUBG berlangsung baik saat berlatih maupun bertanding dapat dikatakan sebagai interaksi virtual. Hal ini dikarenakan ketika berada dalam game online (PUBG), setiap anggota tim yang ikut bermain akan saling berkomunikasi baik menggunakan fitur yang telah disediakan oleh game itu sendiri ataupun menggunakan aplikasi tertentu yang dikhususkan untuk berkomunikasi

\section{Pola Komunikasi Kelompok}

Berdasarkan kajian teori, terdapat tiga alur dalam menjelaskan pola komunikasi suatu kelompok. Pertama, identifikasi peristiwa yang terjadi secara berulang. Dalam kasus tim Redlineze ini, peristiwa yang sering terjadi adalah kegiatan bermusyawarah untuk mencapai suatu keputusan. Inventarisasi komponen komunikasi yang membangun peristiwa komunikasi yang berulang tersebut. Berdasarkan wawancara penulis, terdapat beberapa unsur yang membangun peristiwa tersebut, yaitu adanya keputusan yang harus dibuat, adanya opini dari rekan satu tim, dan adanya keputusan pemimpin. Ketiga adalah menemukan hubungan antar komponen komunikasi yang membangun peristiwa komunikasi. Dalam tim Redlineze, maka keputusan yang harus dibuat memicu adanya musyawarah. Musyawarah ini menuntut pemimpin untuk mengambil keputusan. Lalu, dari musyawarah tersebut muncul opini dari rekan satu tim, kemudian baru mereka membuat keputusan.

\section{Kerjasama Tim}

Faktor-faktor yang melatarbelakangi perlunya dibentuk tim, khususnya dengan kerja sama yang baik, adalah (1) pemikiran dari dua orang atau lebih cenderung lebih baik dari pada pemikiran satu orang saja, (2) konsep sinergi (yang disimbolkan: $1+1>2$ ), yaitu bahwa hasil keseluruhan (tim), jauh lebih baik dari pada jumlah bagiannya (anggota individu), (3) anggota tim dapat saling mengenal dan saling percaya, sehingga mereka dapat saling membantu, dan (4) kerjasama tim dapat menyebabkan komunikasi terbina dengan baik.

Dalam hasil penelitian, faktor kerja sama tim tampak pada tim ini, karena pemikiran dari dua orang atau lebih cenderung lebih baik dari pada pemikiran satu orang saja. Ketika pada saat menganalisa strategi lawan. Faktor saling percaya dan membantu pada setiap anggotanya juga membuat tim menjadi lebih konsisten dan kuat. Faktor kerjasama tim juga dapat menyebabkan komunikasi terbina dengan baik, tampak pada evaluasi tim usai bermain.

\section{Simpulan}

Tim Redlineze E-Sports sebagai objek dari penelitian ini memenuhi aspekaspek pola komunikasi yaitu pola komunikasi sirkular dan pola komunikasi linear. Pertama, pola komunikasi sirkular adalah pola komunikasi yang bulat, bundar atau keliling. Pola komunikasi sirkular dapat dilihat dari proses komunikasi interpersonal antar anggota tim. Pola komunikasi sirkular ini juga dapat dilihat ketika dalam proses musyawarah pengambilan keputusan.

Kedua, pola komunikasi linear, yaitu proses komunikasi yang bersifat lurus atau proses penyampaian pesan oleh komunikator kepada komunikan sebagai titik terminal. Pola komunikasi ini dapat kita lihat pada saat terjadinya penyampaian hasil musyawarah dari pemimpin tim yang telah disepakati oleh seluruh anggota tim. 


\section{Ucapan Terima Kasih}

Peneliti mengucapkan banyak terima kasih yang sebesar-besarnya kepada narasumber Doyu Maulana, Abdillah Ilhaq, Malik Abdul Aziz, Rizky Hibatulloh atas ketersediannya dalam membantu menyelesaikan penelitian ini. Terima kasih juga atas dukungan dari banyak pihak yang juga membantu hingga terselesaikannya penelitian ini.

\section{Daftar Pustaka}

Astuti, Angggraini dan Leonard. (2015). Peran Kemampuan Komunikasi Matematika Terhadap Prestasi Belajar Matematika Siswa. Institute for Research and Community Services. Jakarta: Universitas Indraprasta PGRI

Dede, R. (2018). Konseling di Sekolah Pendekatan-pendekatan Kontemporer. Jakarta: Prenadamedia Group.

Effendy, Onong Uchjana. (2017). Komunikasi Teori dan Praktek. Bandung: Remaja Rosdakarya

Hapsari, D. R. (2015). Peran Jaringan Komunikasi Dalam Gerakan Sosial Untuk Pelestarian Lingkungan Hidup. ASPIKOM, 25-36.

Kustiawan, A. A., \& Utomo, A. W. (2019). Jangan Suka Game Online Pengaruh Game Online Dan Tindakan Pencegahan. Magetan: Ae Media Grafika.

Moleong, L. J. (2010). Metodologi Penelitian Kualitatif. Bandung: Remaja Rosda Karya.

Nasrullah, R. (2014). Teori dan riset media siber. Jakarta: Prenadamedia Group.

Susanto, E. H. (2017). Komunikasi Sepadan Dalam Pembangunan Daerah (Studi tentang Pola Komunikasi Untuk Mewujudkan Visi Riau 2020). Karya Ilmiah Dosen, 41-47.

Widjaja. (2010). Tujuan Komunikasi. Jakarta: Erlangga.

Yin, Robert K. (2014). Studi Kasus Desain \& Metode. Jakarta: Rajawali Pers. 